The Book of Wisdom and Lies (Kelmscott Press) and Visramiani (Oriental Translation Fund). His interest in everything relating to Georgia dated from the period of his youthful travels in that country, of which he published an account as early as 1888 .

W. Foster.

\title{
Ernst E. Herzfeld
}

Few scholars of our generation have contributed so much to increasing our knowledge of the sources for the study of ancient Western Asia in periods or directions of which little was previously known as Ernst Herzfeld. An established scholar of considerable reputation not only in his own University, Berlin, by 1910, his early work was encouraged by Eduard Meyer, the historian, and aided by the active co-operation of Friedrich Sarre, whose outstanding achievements there has yet been little chance to appreciate. Friendship and co-operation with Koldewey and the archæological architects of the mission of the Deutsche Orient-Gesellschaft in Iraq, led him to admire their methods and made him a sound fieldworker, without obscuring his firm understanding of the necessity for combining the study of language and history with archæology if the tasks before him were to be accomplished.

His training fitted him for the very diverse tasks he undertook. On his many journeys he continually noted new sites, and thus pointed the way for many later excavations, particularly in Persia. At some sites already well known he carried out fresh work unexpectedly rich in results, notably at Samarra and Persepolis. $\mathrm{He}$ continually brought to our attention neglected subjects, such as the nature of the metal-working craft in the first millennium B.c. at Wan, the significance of the designs on scratched button seals of early date from Anatolia, the importance of Sassanian gems and of coins for the study of larger monuments, the relevance of the façades of rock tombs in the hills of Kurdistan to the development of architectural types, the standing monuments in remote, often previously unvisited areas in Persia. Everywhere he found and published new inscriptions, Akkadian, Old Persian, Aramaic, and Arabic, many of which might have been permanently lost through the activities of ignorant dealers, or might have remained unnoticed by less indefatigable travellers. It is impossible, and unnecessary to enumerate his publications ; they are well known and will remain source books for such studies for a long time. 
The changed conditions in Germany after 1933 were a heavy blow to him, though we did not all, perhaps, understand how heavy. His father had, I think, been a medical officer in the German army, and he was much attached to old traditions. During the bad years he spent liberally in scientific publication, then finally went to Princeton to further advanced studies there; when his time came to retire, he travelled to Cairo for the purpose of completing Max van Berchem's work. During those last years he was involved, as any man who undertakes much pioneer work always is, in a number of controversies. His writing, always a little too compressed for clear reasoning in exposition, for he aimed, as he said somewhere, at that impossible goal "to express everything mathematically", became much involved in the difficulty of using a foreign language, the plague of our time. In spirit, as was obvious from his letters, he was much depressed, no doubt owing to ill health. In Cairo he fell ill, went to Switzerland for treatment, and died there.

One who benefited from many opportunities for long, and sometimes heated, conversations with him under many different conditions, may be allowed to bear witness to his culture, to the intellectual power he brought to the consideration of detail in the wide field he covered, and to his power to stimulate in new directions. Younger men felt bound to differ from his views, and he never failed to reply; even where he persisted in what appear mistaken opinions, there was something to be learnt. I have not read anything he wrote from which I have not received instruction, leaving some impression from a sensitive and trained mind. But his conversation was better than his books. To the wide circle of those who appreciated his own passion for the beautiful or admired his wide knowledge, without claiming themselves any right to judge him as philologist or archæologist, his passing will bring great regret. He was a loyal friend of this Society.

SidNey SMith. 